\title{
ANALISIS FORMAL FASAD ARSITEKTUR RUMAH TINGGAL ORANG TORAJA DI KOTA PALOPO
}

\author{
Moh Sutrisno ${ }^{1 *}$ Ahmad Sarwadi ${ }^{2}$ \\ Universitas Islam Negeri Alauddin Makassar ${ }^{1}$, Universitas Gadjah Mada ${ }^{2}$ \\ e-mail: *1moh.sutrisno@mail.ugm.ac.id, ${ }^{2}$ sarwadi@ugm.ac.id
}

\begin{abstract}
Abstrak_Penelitian ini mengkaji fasad arsitektur rumah tinggal masyarakat Toraja yang ada di Kota Palopo. Arsitektur yang bersifat tradisi cenderung dinamis. Dari waktu ke waktu cenderung mengalami perubahan, serta dari tempat satu ke tempat lain cenderung mengalami adaptasi. Metode penelitian kualitatif dengan paradigma rasionalistik. Hasil menunjukkan kondisi dan keadaan lingkungan yang berbeda antara Palopo dan Toraja berpengaruh pada perwujudan dan transfromasi bentuk sehingga terjadi perubahan aspek fisik. Berdasarkan analisis dengan parameter teori proporsional garis simetri dan golden section menyimpulkan bahwa ukuran bangunan rumah tinggal berbentuk tongkonan mendekati proporsional golden section. Hirarki fungsi pada pembagian ruang atas, ruang tengah dan ruang bawah tidak diterapkan secara jelas oleh masyarakat suku toraja yang ada di Palopo. Kebutuhan fungsional pada tata ruang rumah menjadikan penggunaan hirarki ruang vertikal berubah fungsinya. Semua elemen atapnya tidak ditopang oleh tulak somba. Kesimpulan secara keseluruhan objek penelitian bahwa bentuk arsitektur tradisional di Palopo bersifat proporsi, metaforis dan monumental.
\end{abstract}

Kata kunci: Rumah Tinggal; Proporsi; Golden Section; Fasad.

\begin{abstract}
This study examined the architectural of residential facades of the Toraja community in Palopo City. Traditional architecture tends to be dynamic. From time to time it tends to change. And from one place to another tends to adapt. This study applied a qualitative research method with rationalistic paradigms. The results showed that different environmental conditions between Palopo and Toraja affect the manifestation and transformation of forms so that there are changes in physical aspects. Based on the analysis with the theory parameter of symmetry line proportional and the golden section concludes the size of the house building in the form of a tongkonan approaching the proportional golden section. The hierarchy of functions in the division of upper space, the middle room, and lower space is not applied by the Toraja tribe community in Palopo. Functional requirements in the spatial layout of the house make use of the vertical space hierarchy change its function. All elements of the roof are not supported by tulak somba. The overall conclusion of the research object on traditional architectural forms in Palopo is proportional, metaphorical and monumental.
\end{abstract}

Keywords: Dwelling house; Proportion; Golden section; Facade.

\footnotetext{
${ }^{1}$ Universitas Islam Negeri Alauddin Makassar

${ }^{2}$ Universitas Gadjah Mada
} 


\section{PENDAHULUAN}

Arsitektur tradisional memiliki prinsip-prinsip keilmuan yang berbeda dengan arsitektur modern. Desain arsitektur tradisional dapat beradaptasi dengan kondisi lingkungan alam, material dari alam, sedangkan arsitektur modern dibangun dari hasil penerapan teknologi yang serba mesin begitu juga material bangunan yang digunakan. modernisme dalam arsitektur selalu menunjukkan pada sesuatu yang bersifat kongkrit dan konsep yang jelas sedangkan arsitektur tradisional menunjukkan sesuatu bersifat abstrak, spiritual dan religius(Sumalyo 2004). Penelitian terkait Morfologi Tana Toraja yang digambarkan Sumalyo mencakup sebagian Tana Luwu sedangkan dalam penelitian lain bahwa luasan daerah Tana Luwu mencakup hampir separuh Tana Toraja, selaras bahwa secara adat bahwa bangsa Luwu yang ada di daerah Toraja dan di daerah Matano diberikan otonomi khusus oleh pihak kedatuaan Luwu (Sutrisno 2019)

Tongkonan merupakan karya arsitektur tradisional di Sulawesi Selatan yang masih kental dengan nilai-nilai spiritual. Bahkan pada beberapa desa adat di Tana Toraja masih tampak wujud arsitekturalnya seperti di desa Siguntu, Ketekesu maupun di Palawa. Namun Arsitektur Tongkonan tidak hanya berada di Tana Toraja, tetapi juga di tempat lain yaitu di Kota Palopo. Di pusat Luwu raya (Palopo) banyak orang Toraja yang membangun rumah tinggalnya dengan ciri khas Tongkonan. Kota Palopo terdiri dari beragam etnis seperti Makassar-Bugis-Toraja yang merepresentasikan etnis yang ada di Sulawesi Selatan. Etnis Bugis-Makassar-Toraja memiliki falsafah kebudayaan dan nilai filosofi yang terangkum dalam terminologi yang disebut pangadereng (Jayadi and Cahyadi 2019). Adanya suku Toraja di Palopo tidak terlepas adanya relasi tentang mitologi lakipadada. Van Lijf menjelaskan bahwa perkawinan lakipadada dengan putri raja Gowa menghasilkan empat raja yang masing-masing berada di gowa bergelar Somba, di Sangalla Toraja bergelar puang, di Luwu bergelar payung dan di Bone Bergelar Mangkau (Mulyadi 2013). Sedangkan Toraja yang berada di daerah Palopo termasuk dalam wilayah adat dima'dikai. Demikian juga dengan bentuk rumah orang Toraja di Palopo cenderung mengalami perkembangan atau bahkan mengalami perubahan dari bentuk aslinya.

Bangunan yang ditentukan adalah rumah berbentuk tongkonan Toraja yang berada di Kota Palopo. Menurut Tangdilinting bahwa rumah tradisional Toraja terbentuk berdasarkan kepada pandangan keyakinan leluhur aluk todolo' dan kepercayaan kosmologi sehingga terwujud sistem struktur rumah menjadi 3 bagian utama yaitu sallu banua, kalle banua dan rattiang banua(Sir et al. 2015). Dalam tata letak dan orientasinya, tongkonan tradisional mencerminkan struktur mikrokosmos (De Jonge 1991). Rumah masyarakat toraja di Palopo terindikasi masih memiliki kaidah-kaidah lokal dengan bentuk yang bercirikan Tongkonan Toraja. Tidak hanya di Palopo yang memiliki karya arsitektur khas Toraja tetapi juga di daerah yang bersebelahan dengan Toraja yaitu daerah Enrekang. Rumah tradisional Duri di Enrekang memiliki wujud yang cenderung berada diantara bentuk arsitektur bugis dan arsitektur Toraja (Zulkarnain AS 2015). Tidak dapat dipungkiri bahwa arsitektur Toraja berpengaruh terhadap bentuk bangunan lainnya. Selain dikenali melalui bentuk atap, tetapi juga dikenali melalui ukiran. Penanda berupa ukiran dan simbol di rumah tongkonan merupakan perwujudan makna filosofis dan spiritual dari kehidupan suku toraja (Lebang 2015). Ukiran memiliki arti dan makna nilai-nilai kehidupan dan kosmologi yang mereka yakini.

Palopo merupakan salah Kota di Sulawesi Selatan yang bukan suatu kabupaten, melainkan telah berada pada struktur pemeritahan Kota. Diantara beberapa universitas di Kota Palopo masih sangat minim program studi arsitektur. Dengan demikian, menjadi penyebab minimnya akademisi 
atau peneliti di daerah setempat yang mengkaji tentang arsitektur. Sebagai suatu Kota, Palopo cenderung belum tampak identitas kotanya jika ditinjau dari aspek arsitektur modern. Akan tetapi, keberadaan Masjid Jami Palopo sebagai Masjid Jami tertua di Sulawesi Selatan menjadi magnet tersendiri bagi Kota Palopo. Karya arsitektur lama lainnya seperti arsitektur kolonial, arsitektur tradisional yang sudah mulai tersisih oleh bangunan-bangunan baru yang cenderung melupakan konteks budaya Luwu. Luwu raya sebagai pusat dari beberapa wilayah Luwu lainnya yang memiliki kebudayaan arsitektur tradisional, Akan tetapi kurang menonjol seperti arsitektur Toraja. Meskipun demikian, suatu seminar heritage di Palopo pada tahun 2017 memadukan antara tana Luwu dan Tana Toraja dan menyoroti tentang bangunan apa yang lebih menonjol sehingga dapat menjadi identitas dan simbol kota Palopo (Sutrisno, Sastrosasmito, and Sarwadi 2019).

Masyarakat Indonesia meyakini bahwa arsitektur tradisional merupakan hasil karya turun temurun dari nenek moyang selama berabad-abad lamanya. Toraja memiliki sense of identity, hal itu dibuktikan rumah-rumah leluhur dan upacara pemakaman yang besar yang menunjukkan rasa kekeluargaan dan menjadi poin utama pada kehidupan mereka tidak hanya di Tana Toraja tetapi juga di luar Tana Toraja(Taylor 2014). Taylor juga mengatakan bahwa sejauh ini penelitian antropologi dan etnografi telah menitikberatkan untuk pendokumentasian budaya dan aspek simbolis dari upacara Toraja terutama upacara pemakaman yang rumit yang menjadi aspek terpenting dari budaya Toraja. Konflik kebudayaan di Toraja secara internal sesama suku Toraja cenderung terjadi yang disebabkan oleh upacara kematian rambu solo', namun sebaliknya terdapat nilai-nilai tongkonan yang mengikat sehingga konflik dapat dihindari (Panggarra 2014). Kerawanan terjadinya konflik juga disebabkan oleh signifikannya tongkonan beserta propertinya dalam hal pengurusan siapa yang dapat mengurusnya (Idrus 2016). Secara eksternal, Toraja dikelilingi suku lain seperti Bugis dan Makassar di dataran rendah, Toraja yang berada di dataran tinggi memiliki kesatuan identitas etnik yang kuat dibalik periode konflik antar agama dan antar etnis beberapa tahun terakhir(Adams et al. 2015). Bagi orang Luwu, suku yang berada di atas gunung disebut To riaja, yang kemudian menjadi kata Toraja (Sutrisno, Sudaryono, and Sarwadi 2018).

Suatu fenomena yang menarik menjadi preseden heterogenitas suku dan agama dalam ruang Kota. Sehubung berkembangnya tipologi rumah tongkonan di luar Tana Toraja menjadi fenomena permasalahan sekaligus menjadi potensi keberagamanan suku. Paradigma yang terbangun di kalangan para pemuda dalam membawa identitas daerah misalnya orang Palopo dan orang Toraja. Terkadang terjadi perselisihan jika berada di Kota Makassar, namun kontradiksi dan realita sebaliknya jika berada di Palopo. Sub etnis Toraja yang berada di Palopo bebas memunculkan identitasya. Salah satu bentuk identitas mereka berupa karya arsitektur rumah tinggal. Adanya bentuk yang berestetika dan simbolik menjadi salah satu indikasi yang layak untuk dijadikan objek penelitian dalam arsitektur. Atap yang besar memang didedikasikan untuk menciptakan ekterior yang mengesankan akan tetapi tidak sebanding dengan ruang interior tongkonan yang kecil yang hanya terdiri dari tiga kamar. Mengingat disiplin arsitektur merupakan kajian yang mengerucut pada aspek fungsi, bentuk, ruang bahkan lebih mendalam pada makna. Penelitian ini bertujuan untuk mengkaji elemen bentuk arsitektural yang ditampakkan secara menonjol oleh masyarakat Toraja yang berada di Kota Palopo serta menggali relasi antara bentuk yang ada dengan bangunan lainnya di ruang Kota Palopo 


\section{METODE}

Paradigma penelitian ini menggunakan paradigma kualitatif rasionalistik. Pendekatan rasionalistik mengajarkan rancangan penelitian dimulai dengan kerangka teori dari hasil penelitian sebelumnya(Muhadjir 2011). Rujukan dapat berupa hasil penelitian, teori yang telah teruji berulang kali dan hasil pemikiran pakar. Selanjutnya dengan berlandaskan pada filsafat rasionalisme, peneliti membangun pemahaman intelektual dan berfikir rasional untuk melakukan argumentasi ilmiah yang logik. Ilmu diperoleh dari bangunan berfikir rasionalisme didukung dengan relevansi data yang dipilih berupa data empirik. Rasionalisme mencakup pendekatan positivisme pada beberapa aspek, yaitu fakta, minimnya teori, proses saat melakukan analisis dan sintesis serta dalam melakukan argumentasi dan memandang realitas. Tahapan penelitian secara garis besar terdiri dari dua tahapan, yaitu: 1) konstruksi teori menjadi suatu kerangka definisi operasional penelitian. 2) Melakukan verifikasi teori. Pada tahapan ini melakukan analisis dengan parameter teori proporsi. Analisis formal terhadap bentuk bangunan dengan memilih teori golden section. Kriteria bentuk merujuk kepada diskursus (Norberg-Schulz 1965) tentang form as proportion, form as space dan form as structure.

Adapun langkah-langkah penelitian terdiri dari beberapa tahapan yaitu penyusunan kerangka konseptual penelitian, observasi awal, penelitian lapangan (observasi dan wawancara), analisis dan kesimpulan. Penyusunan kerangka konseptual merupakan upaya untuk merumuskan teori yang spesifik untuk dilakukan verifikasi di lapangan. Adapun grand theory yang akan digunakan sebagai acuan untuk verifikasi adalah teori proporsi yaitu golden section. Langkah selanjutnya adalah melakukan penelitian lapangan dengan cara pengumpulan data primer. Data primer selanjutnya direduksi dan dipilih data yang relevan dengan fokus fasad bangunan rumah tinggal orang Toraja yang ada di kota Palopo. Selain melakukan observasi, penelitian lapangan juga melakukan wawancara terhadap orang asli Toraja yang bermukim di Kota Palopo. Wawancara dilakukan untuk mengetahui beberapa kelurahan yang dihuni mayoritas suku Toraja. Waktu penelitian lapangan dilakukan pada bulan agustus hingga obktober tahun 2017. Sedangkan alatalat yang digunakan adalah kamera digital, alat perekam suara, meter dan log book. Adapun kategorisasi objek yang diukur tidak berdasarkan kuantitas akan tetapi berdasarkan kualitas fasad bangunan. Kemiripan objek-objek rumah tinggal yang tersebar wilayah perbatasan Palopo-Toraja dan sepanjang jalan Batara, kota Palopo, merupakan wilayah yang menjadi lokus penelitian. Area pemukiman orang Toraja ditandai oleh adanya jalan yang menghubungkan antara Toraja Utara dengan Kota Palopo. Objek yang diukur dan dipilih berdasarkan jumlah longa yaitu 1 longa dan 2 longa. Adapun pengukuran fasad bangunan tiap-tiap objek tidak bertujuan untuk melakukan komparasi antara objek yang satu dengan objek yang lainnya akan tetapi bertujuan untuk melakukan eksplorasi terhadap kekhasan masing-masing fasad rumah tinggal orang Toraja.

\section{A. Form as proportion, form as space, form as structure}

Bentuk merupakan wujud akhir hasil pemikiran dari organisasi ruang dan konstruksi yang tampak sebagai benda-benda. Salah satu ciri visual dari bentuk yang telah dikemukakan oleh DK. Chingadalah dimensi(Ching 1979). Berdasarkan dimensi inilah bentuk dalam arsitektur dapat dijabarkan tingkat proporsionalnya. Selaras dengan Norberg-Schulz bahwa"We have shown that the ratios as such do not warrant a satisfactory architectural form. 'Rules of proportion' only have an ordering effect when they lead to concrete architectural gestalten. The concrete Gestalt is decisive, not the invisible mathematical relations. The psychology of perception shows that Gestalt is only rarely correlated with particular munerical relations"(Norberg-Schulz 1965). 
Bentuk sebagai proporsi dalam penelitian ini mengarah pada analisis bentuk bangunan dalam kondisi seimbang. Adapun bentuk yang dianalisis adalah bentuk rumah suku Toraja di Palopo pada aspek fasad secara utuh. Makna dan fungsi sebuah bangunan dapat ditunjukkan oleh elemen fasad bangunan dan fasad merupakan bagian depan rumah yang menghadap ke jalan (Marwati and Ikrama 2018). Teori proporsi yang dijadikan pendekatan adalah tiga dari enam teori yang dikemukakan oleh Ching. Tiga teori proporsi tersebut adalah Golden Section, modular dan proporsi manusia.Simetri (refleksi) adalah pencerminan objek pada sebuah garis sebagai bidang cermin (Rahadian et al. 2013). Pada proses refleksi, nilai objek Sama dengan nilai refleksi objek. Dengan adanya parameter simetris, Akan tampak suatu bangunan jika garis pencerminan berada di tengah-tengah, maka bangunan tampak sama besar dan identik.

Koentjarannigrat dalam (Stephany 2011) mengungkapkan wujud ruang yang dihadirkan menjadi benda budaya akan terkait dengan sistem sosial budayanya. Ia juga menyatakan bahwa setiap bentuk dari wujud benda budaya selalu mengalami perubahan karena budaya tersebut mencerminkan kepercayaan, sudut pandang, sistem sosial masyarakatnya. Manusia tidak terlepas dari hal-hal dalam penciptaan ruang, sebagai contohnya adalah rumah.Bentuk sebagai ruang yang dimaksud dalam kajian ini adalah eksistensi dari bentuk yang merupakan representasi dari ruang. Indikasi bentuk yang berbeda cenderung mewakili kebutuhan ruang ataukah lebih mementingkan aspek lain selain ruang. Dengan menggunakan konsep ini, kasus akan dianalisis pada aspek bentuk rumah tongkonan.

Struktur dalam arsitektur merupakan aspek yang sangat penting. Merujuk pada analisis'bentuk sebagai struktur' yang dijelaskan oleh Norberg-Schulz akan dijadikan pendekatan analisis kasus penelitian. Bentuk hadir sebagai struktur yang menjadi kesatuan yang utuh. Selain itu terbentuknya struktur dipengaruhi oleh elemen spasial. Aspek lain dari pemakaian struktur bergantung dari bahan yang digunakan. Analisis pada kasus penelitian, apakah telah memenuhi kriteria bentuk merupakan representasi dari struktur.Meninjau dari hasil penelitian sebelumnya bahwa tiga sistem struktur (bagian bawah, bagian tengah dan bagian atap) dari tongkonan dapat berdiri sendiri (Sir et al. 2015). Sistem struktur tiap bagian juga berbeda-beda. Dari ketiga sistem menghasilkan sistem yang saling menopang antara bagian satu dengan yang lainnya. Namun secara eksplisit tidak dijelaskan apakah dari rangkaian sistem tersebut selalu rigid dalam menghasilkan bentuk.

\section{B. Golden Section}

Proporsi merupakan salah satu teori dasar dalam mempelajari ilmu arsitektur. Salah satu ilmuan yang secara eksplisit menjelaskan tentang teori proporsi adalah D.K. Ching. Beberapa teori proporsi terdiri dari enam teori yaitu: 1) the golden section 2) the orders 3) renaissance theories, 4) the modular, 5) the 'ken', dan 6) anthropomorphic proportions (Ching 1979). Golden Section memberikan rumus matematika dengan memperbandingkan bidang yang satu terhadap bidang lainnya dengan hasil perbandingan 1,618. Sistem perbandingan tersebut mengarah akan terciptanya relasi konsistensi yang baik antara bagian-bagian elemen maupun keseluruhan komponen bangunan (Sani, Supriyadi, and Rukayyah 2015). Dalam teori arsitektur lainnya dikemukakan Mallgrave tentang pengakuan dasar antropomorfik dan proporsi suatu objek; “These stories are sometimes said to compose the 'mythology' of architecture, fables that were eventually discredited by the rational forces of the Western Enlightenment, but once again they demonstrate the anthropomorphic basis of Vitruvian theory. One sentence within this passage that should not be overlooked is his admission that the 
proportions for both the Doric and Ionic columns changed after some progress in refinement and delicacy of feeling"(Mallgrave 2006).

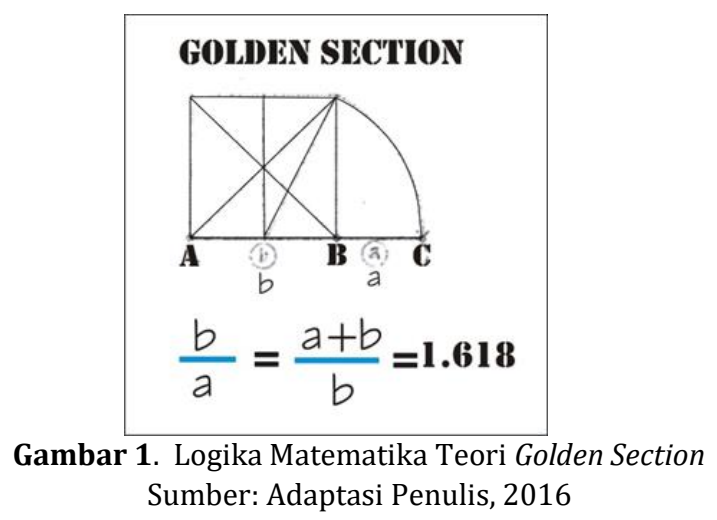

\section{HASIL DAN PEMBAHASAN}

\section{A. Rumah Tinggal Representasi Dua Longa}

Masyarakat palopo yang berasal dari Toraja mempunyai ciri khas tersendiri dalam tatanan kehidupan bermasyarakat, salah satunya tampak pada bentuk rumah tinggalnya. Rumah tinggal yang bercirikan tongkonan tidak ada kesamaan bentuk yang identik antara rumah satu dengan rumah yang lainnya. Dari beberapa hunian, dipilih tiga objek rumah tinggal yang dinilai mampu merepresentasikan hunian dengan corak tongkonan lainnya. Pemilihan didasarkan pada perbedaan yang menonjol, lebar penampang tongkonan dan tinggi atap.

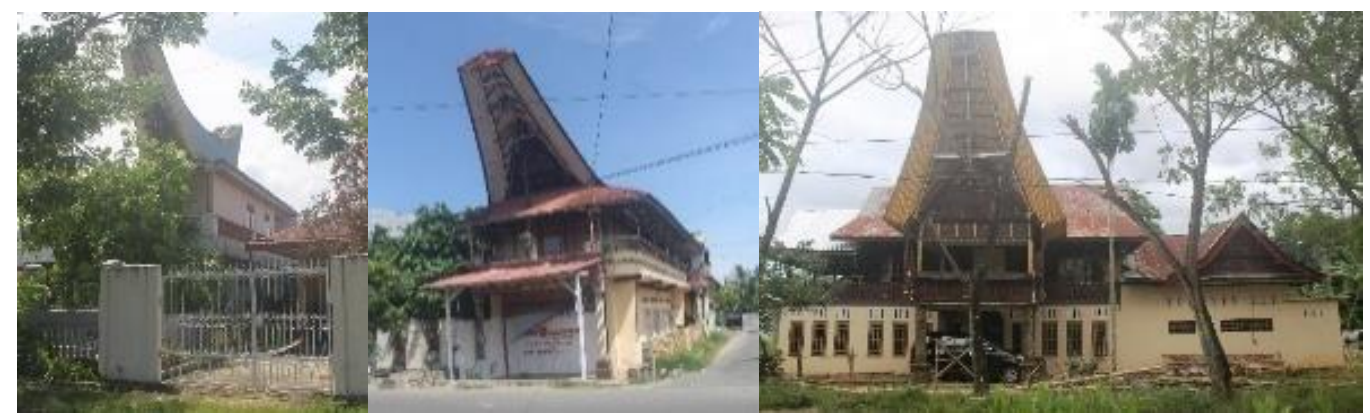

Gambar 2. Variasi Atap Rumah Orang Toraja di Palopo. Sumber: Dokumentasi penulis, 2016

Bentuk rumah tinggal yang ada di Kota Palopo secara umum tidak menunjukkan bentuk yang mencolok. Rumah tinggal masyarakat Palopo berupa rumah tinggal dengan tipologi seperti pada umumnya rumah tinggal masyarakat kebanyakan di nusantara. Masyarakat kebanyakan yang peneliti maksud adalah rumah dengan susunan ruang terdiri dari teras, ruang tamu, kamar tidur, ruang keluarga, dapur dan kamar mandi / WC. Rumah dibangun diatas permukaan tanah dengan ketinggian dinding kurang lebih $3 \mathrm{~m}$ dan hanya terdiri satu lantai. Bentuk atap berupa atap pelana, perisai atau kombinasi antara pelana dan perisai. Dalam satu pekarangan rumah, kebanyakan memiliki pintu gerbang dengan ciri-ciri tipologi atap bersusun tiga. Susunan ukuran mulai atap paling bawah terbesar, bertumpang dengan ukuran yang lebih kecil diatasnya, atap paling atas semakin kecil. Keseluruhan bentuk pintu gerbang semakin keatas semakin kecil.

Selain itu, berdasarkan observasi, peneliti mendapatkan beberapa masyarakat yang membangun rumahnya dengan atap tongkonan. Beberapa rumah toraja yang tampak pada gambar di atas merupakan tiga contoh sampel rumah yang terdapat di salah satu pemukiman di 
Kota Palopo. Bentuk dan ukuran dari atap rumah yang berbentuk atap tongkonan cenderung memiliki perbedaan antara rumah yang satu dengan rumah lainnya. Atap rumah yang menjadi penutup seluruh bangunan memiliki kesamaan pada wujud secara umum yang menyerupai tanduk kerbau ataupun perahu. Ujung dari kedua sisi (bagian depan dan belakang) menjorok keluar badan rumah dan menjulang tinggi. Sedangkan untuk badan rumah seperti rumah masyarakat pada umumnya.

Dinding rumah tidak terbuat dari struktur kayu yang terukir dengan simbol-simbol kehidupan. Dinding rumah dibangun dengan material modern seperti batu bata dan dilapisi dengan plesteran campuran semen dan pasir. Bentuk bangunan secara verikal terdiri dari tiga bagian, adapun dinding berada pada bagian badan rumah dan bagian kaki rumah. Bagian kaki rumah ditutup dengan dinding permanen sehingga rumah masyarakat Toraja yang ada di Palopo tampak terdiri dari dua lantai.

\section{B. Rumah Tinggal Tipe A.}

Bentuk rumah tinggal pada objek A adalah bentuk rumah tinggal dengan atap mirip dengan tongkonan yang terdapat di Tana Toraja. Struktur atap yang membedakan adalah lebar dari penampang atap lebih tampak sempit jika dibandingkan dengan tongkonan aslinya. Perbedaan antara lebar dan panjang sejak dulu telah dipaparkan oleh Tangdilintin dalam Sumalyo (2004) dengan variasi perbandingan lebar : panjang = $1: 2$ hingga $1: 5$. Pada kasus ini, perbandingan lebar dan panjang diperkirakan 1:2 yang dapat dinilai sebagai suatu proporsi perbandingan yang indah dan serasi.

Tabel 1: Analisis bentuk, elemen atap, simetri dan verifikasi teori golden section terhadap bangunan A
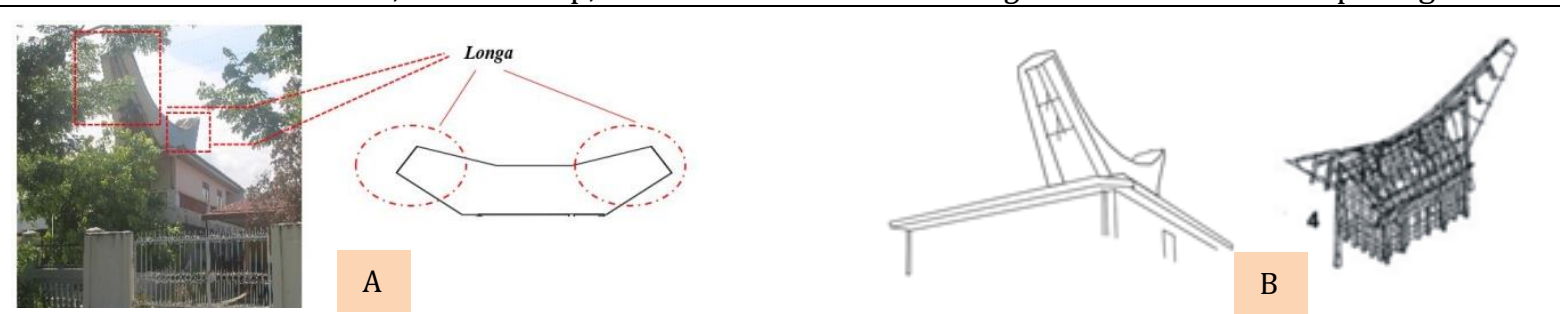
A. Longa yang diterapkan pada bangunan dua lantai berjumlah dua longa
B. Komparasi dengan bentuk tongkonan di Toraja
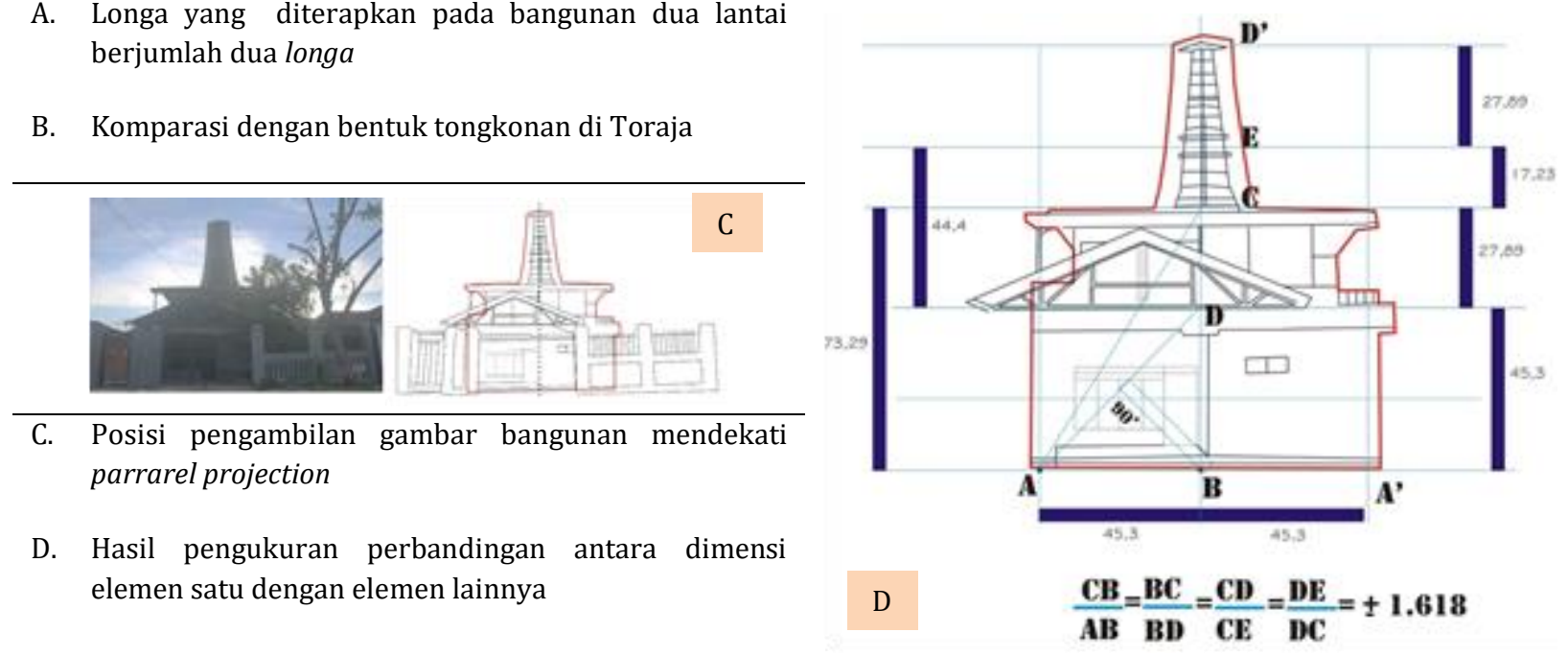

Sumber: Analisis dan interpretasi penulis, 2016 
Longa (ujung depan dan belakang yang menjulang keatas) lengkap dengan memiliki bagian depan dan bagian belakang. Hal itu yang masih sama dan mencirikan arsitektur tongkonanaslinya. Di lain sisi, kelengkapan longa merupakan pembeda bagi objek lainnya yang dianalisis dalam kajian ini. Dalam beberapa titik di Palopo, dapat dikategorikan ada dua tipe atap berdasarkan kelengkapan longa, yakni longa depan belakang dan longa depan saja. Namun dalam penelitian ini tidak mendalami sampai pada wawancara mengenai makna longa dua dan longa yang hanya satu saja.

Pada umumnya, proporsional atap mimesis dengan tongkonan akan menghasilkan proporsi yang seimbang jika diamati dari tampak samping. Dalam evolusi perkembangan atap, mulai dari awal bentuk tongkonan yang diberi nama banua lentong a'pa' hingga pada bentuk tongkonan berpunggung atap melengkung dalam, tidak pernah didalamnya terdapat proses menghilangkan salah satu sisi longa. Kedua longa selalu muncul bersamaan dan berevolusi bersamaan pula. Kemunculan longa diawali pada perkembangan generasi kedua yaitu pada saat bernama banua tamben (Sumalyo 2004).

Jika ditarik garis sumbu pada posisi bangunan tampak depan, maka akan terbentuk bidang simetris. Pola proporsional sederhana pada analisis sumbu ini dapat dengan mudah dilakukan. Lengkungan atap bagian tengah cukup dalam, hal ini menandakan bentuk atap mengikuti pola evolusi yang terkini. Pada titik pusat lengkungan dapat ditarik garis sumbutampak samping untuk menghasilkan bidang yang simetris.

Ciri umum dari arsitektur tradisional adalah membentuk simbol ikatan antara manusia dengan alam (Sumalyo 2004). Pada kasus rumah Toraja kontemporer, hanya atap yang secara fisik dan mengadobsi secara eksplisit untuk keagungan tempat keberadaan puang matua. Bentuk ini tampak berbeda dengan aslinya yang ada di Toraja. Selaras dengan apa yang dituliskan Stephany (2011) bahwa transformasi bentuk merupakan hasil dari proses sosial budaya. Krier dalam Stephany juga mengungkapkan bahwa karena penetrasi sehingga menjadi salah satu sebab terjadinya perubahan bentuk.

Atap diinterpretasikan sebagai simbolisasi dunia atas. Dengan bentuk menyerupai tanduk kerbau juga perahu, memberikan keunikan tersendiri bagi bentuk rumah arsitektur toraja diantara rumah-rumah tradisional lainnya yang ada di Sulawesi Selatan. Di luar Sulawesi selatan juga terdapat bentuk atap yang mirip dengan atap tongkonan seperti rumah batak dan rumah minang. Rattiang banua juga terindikasi sebagai representasi masih terjaganya kepercayaan pemilik bangunan tentang bagian rumah yang dianggap suci. Dengan tipe hiperbolik meninggi, dalam Sir et al., (2015) menuliskan bahwa longa tidak memiliki tulak somba akan tetapi diganti dengan sistem sub struktur untuk tempat menggantung tanduk kerbau. Ekspresi metaforis dari bentuk atap rumah dapat menciptakan berbagai interpretasi analogi bentuk.

Proses analisis dengan membuat suatu proyeksi titik yang menjadi jarak ukuran proporsi. Dalam kasus objek A, peneliti menambahkan cerminan A' sebagai bentuk cerminan dari titik A.Selain itu, terdapat titik D' sebagai representamen dari titik D. Titik aksen (') sebagai titik bantu untuk mengukur jarak yang sama dari titik terdekat. Dari hasil tarikan garis pada fotoobjek, maka diperoleh wujud dari objek untuk dianalisis berdasarkan simulasi golden section yang telah dikonstruksi untuk mengukur tingkat keseimbangan objek A. Dengan mengambil titik pijak CE sebagai ukuran poros terkecil berbanding CD dengan meminimalisir kondisi distorsi dari suatu ukuran. Prinsip similaritas dari figur atap antar objek yang satu dengan objek yang lainnya masih tetap relevan meskipun dimensi dari suatu bentuk berbeda. 
Substitusi juga dapat dilakukan dalam melakukanperbandingan antar titik yang memiliki ukuran yang sama.

\section{Rumah Tinggal Tipe B.}

Lokasi objek amatan pada kasus B terletak di pinggir jalan raya. Seperti yang telah dipaparkan pada kasus objek A, bahwa objek ini hanya terdiri dari satu longa. Hanya bagian depan yang terdapat longa yang mengarah ke arah utara. Sedangkan bagian selatan tidak terdapat longa. Dalam Sumalyo (2004) dikatakan bahwa masyarakat Toraja tidak mengenal arah mata angin seperti barat, timur, utara danselatan, akan tetapi menggunakan patokan matahari terbit, tenggelam, depan dan belakang. Pada kasus ini, longa hanya ada pada bagian depan bangunan.

Tabel 2. Analisis bentuk, elemen atap, simetri dan verifikasi teori golden section terhadap bangunan B
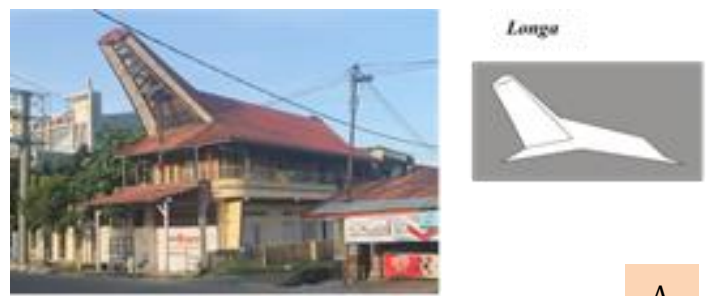

A. Digitalisasi data menggunakan logika matematika golden section. Gambar lapangan dalam posisi mendekati bentuk parallel projection dan terkunci (lock aspect rasio)

A

B. Fasad depan bangunan tampak sumbu yag asimetris dalam satu kesatuan elemen bangunan
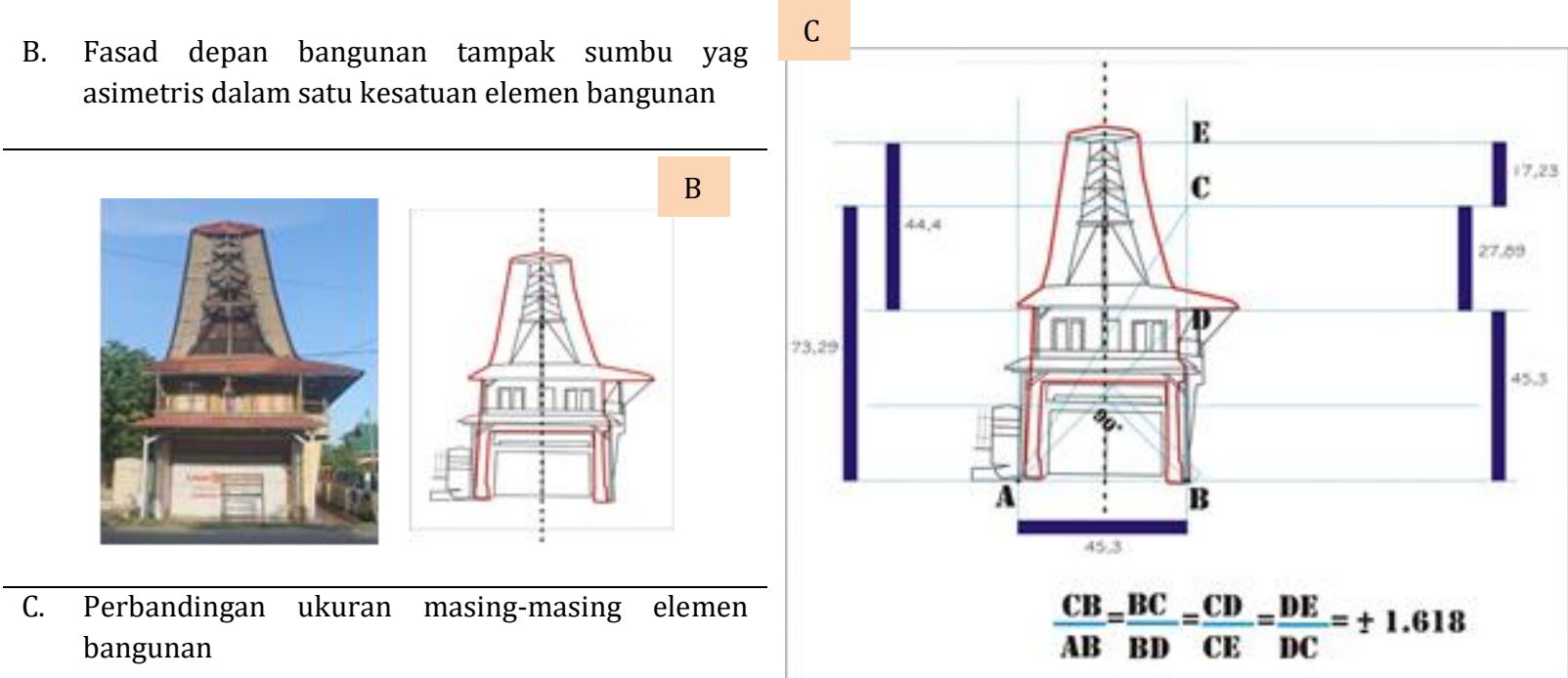

Sumber: Analisis dan interpretasi penulis, 2016

Garis imajiner jika ditarik sumbu vertikal tampak depan bangunan akan mendapatkan bidang yang asimetris. Hal tersebut terjadi karena pemilik rumah memanjangkan atap tambahan pada sisi kiri bangunan. Sedangkan sisi kanan bangunan tetap dalam keadaan pendek dan terkesan terpotong. Tampak proporsi didapatkan jika seluruh unit dan elemen bangunan dalam tapak menjadi suatu kesatuan (unity) dengan memperhatikan pintu pagar besar site bangunan.

Rumah yang berada di era modern masih mewariskan simbol-simbol budaya dan identitas suku tertentu yang kini menjadi identitas nasional. Sebagai objek kebudayaan 
tangible, rumah kasus B dapat menciptakan keseimbangan dengan lingkungan. Komunikasi visual ditampakkan oleh bentuk bangunan berperan dalam memperkenalkan citra kota. Dalam pijakan berarsitektur, wujud yang ditampilkan secara implisit mengandung venustas dari vitruvius atau dalam bahasa Norberg-Schulz sebagai estetika. Secara empiris dan rasional, keindahan timbul dari suatu bentuk yang proporsi dan harmonis.

Penambahan struktur pada bagian sisi kanan bangunan cenderung kontekstual dan fungsional. Posisi bangunan yang berada pada pertigaan jalan raya dimanfaatkan oleh pemilik bangunan untuk menambahkan akses pencahayaan dengan menambahkan bukaan seperti jendela tampak pada bagian bawah dan tengah bangunan. Fungsi tambahan seperti koridor pada bagian tengah bangunan dengan menambahkan ruang yang berfungsi sebagai aksesibilitas. Seperti konsep yang ada bahwa bentuk yang berupa ruang dapat mengakomodasi aktivitas. Penyatuan fungsi dan bentuk fisik menghasilkan tipologi yang berbeda.

Analisis secara formal dan rasional dengan menggunakan teori golden section, bangunan pada kasus B ini mendekati proporsi golden section. Rekonstruksi ulang dari dokumentasi objek tidak sampai pada proses pengukuran secara langsung, akan tetapi melalui pengukuran dengan skala gambar. Gambar lapangan dalam posisi mendekati kualitas parallel projection dan harus dalam kondisi terkunci (lock aspect rasio). Atribut dari fasad sangat menonjol dan simetris yang dilengkapi dengan ukiran khas Toraja serta simbol tanduk kerbau yang digantung pada tiang depan lantai 2. Gambar ayam pada kedua sisi juga dapat menjadi komparasi antara bangunan yang modern dengan bangunan yang ada sebelumnya di Tana Toraja.Sebagaimana bentuk tongkonan yang eksplisit tegas pada visibilitas atap rumah tinggal, objek B sebagai representamen dari anomali wujud atap. Kondisi longa yang hanya satu dapat diklasifikasikan satu kategori dengan pintu gerbang yang juga memiliki satu longa.

\section{Rumah Tinggal Tipe C}

Bentuk bangunan rumah tinggal suku Toraja pada masyarakat kelas menengah keatas memiliki fasad bangunan khususnya pada bentuk atap yang berbeda dengan lingkungannya. Pada strata sosial dengan kondisi ekonomi mampu membangun rumah dengan dilengkapi atap rumah berupa tongkonan. Terdapat variasi bentuk dari fasad atap yang tersebar di beberapa kompleks pemukiman masyarakat Palopo.

Pemukiman suku toraja di Palopo cenderung berkelompok dalam suatu kelurahan tertentu. Namun ditemukan pula pada lokasi terpisah akan tetapi jumlahnya tidak banyak. Pada lokasi mayoritas, suku Toraja masih mempertahankan bentuk tempat tinggalnya dengan tipologi rumah panggung. Bentuk rumah adat yang pada umumnya banyak ditemukan di Sulawesi Selatan yang terbagi atas tiga bagian, yaitu bagian bawah, bagian tengah dan bagian atas. Bagian bawah berupa struktur tiang penyangga sebagai penopang badan rumah dan atap. Pada bagian atap secara fisik dapat menentukan identitas masyarakat Toraja.

Pembentukan kaki hingga atap rumah secara vertikal dapat menunjukkan bentuk yang simetris. Fasad tampak depan, jika ditarik garis lurus pada sumbu tengah bangunan, maka akan terbagi seimbang antara kedua bagian. Simetrical form dimiliki oleh bagian rumah yang menjorok kedepan dan menjadi aksentuasi bentuk terhadap keseluruhan bentuk rumah. Garis vertikal sebagai garis bantu untuk menunjukkan sifat simetris suatu bentuk. Akan tetapi jika ditarik garis bantu secara horisontal pada sumbu tengah tidak diperoleh sifat simetris.

Bentuk rumah tinggal pada kasus C ini termasuk dalam karya arsitektur lokal yang kontemporer. Rumah menggunakan material modern yang terdiri dari tiang menggunakan cor beton bertulang, dinding menggunakan batu bata dan penutup atap menggunakan seng dan 
spandek. Penggunaan material kayu digunakan untuk menutup dinding bagian tengah. Kayu juga digunakan sebagai media ukiran pada dinding luar ornamen atap. Berdasarkan wawancara dengan informan sebagai pemilik rumah, material kayu asli dan didatangkan langsung dari Tana Toraja. Aspek kontemporer juga tampak pada organisasi ruang dan massa bangunan menjadi tunggal. Hal ini berbeda dengan arsitektur tradisional yang berada di Makale yang jumlah bangunannya bermassa.

Tabel 3. Analisis bentuk, elemen atap, simetri dan verifikasi teori golden section terhadap bangunan C

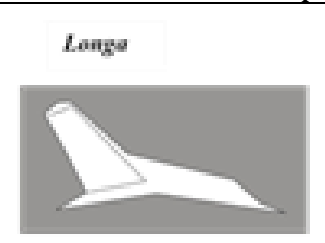

B. Digitalisasi data berdasarkan gambar data lapangan. Pengambilan gambar dilakukan pada posisi seluruh bangunan tampak mendekati bentuk parallel projection.

Gambar bangunan harus selalu terkunci (lock aspect rasio) ketika dilakukan digitalisasi wujud bangunan elemen bangunan.

A. Longa yang diterapkan pada bangunan dua lantai berjumlah satu longa

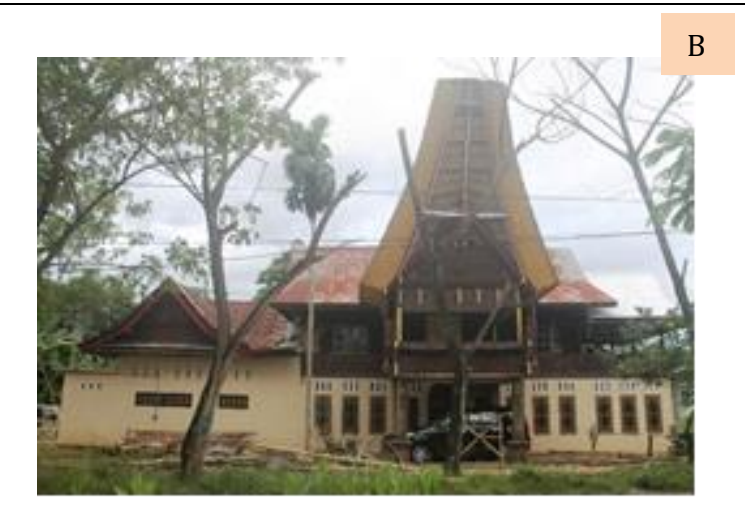

- Tampak samping bangunan

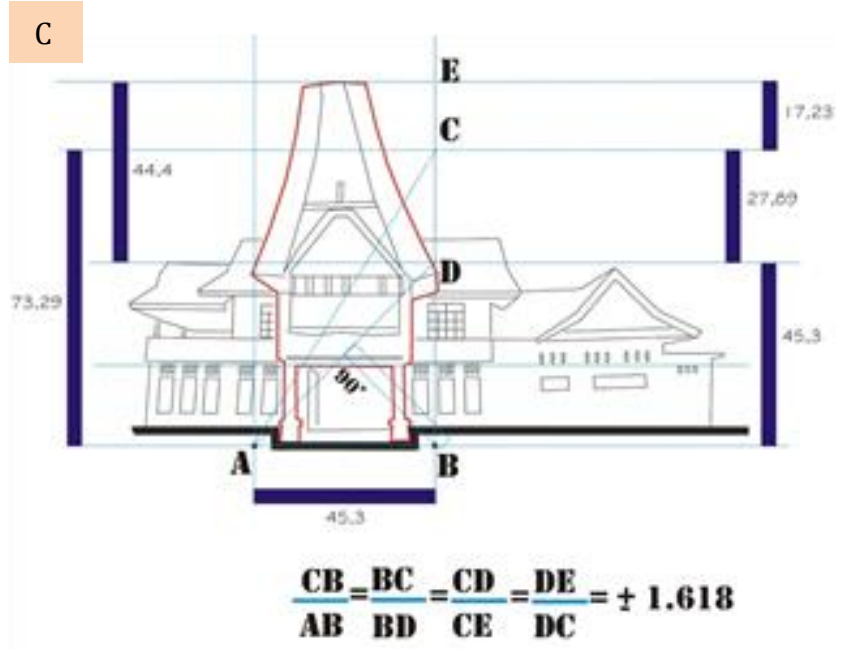

Sumber: Analisis dan interpretasi penulis, 2016

Analisis dengan menggunakan garis bantu horisontal dapat dilakukan dengan pendekatan teori proporsi golden section. Penalaran teoretis dengan proses verifikasi telah dilakukan pada objek-objek rumah tinggal sebelumnya, Akan tetapi penjabaran rumus (gambar 1) secara umum akan disajikan pada bagian ini. Keseimbangan golden section diperoleh jika perbandingan antara panjang garis a berbanding garis $b$ sama dengan jumlah panjang garis a dan $b$ berbanding panjang a, dengan syarat a lebih panjang daripada $b$. Deskripsi diperoleh dari gambar Ching (1979) tentang proporsi bentuk dan ruang. Argumen suatu tanda nalar (a sign of reason) dapat mempertegas eksistensi suatu objek yang memiliki kebenaran proporsi.

Pada bagian bentuk yang merepresetasikan tongkonan memiliki proporsionalitasnya tersendiri. Analisis dimensi atau ukuran dapat dilakukan dengan menggunakan teori golden section. Objek kajian pada setiap kasus dalam penelitian ini memberi rangkaian proporsi objek dengan keragaman bentuk. Relasi antara bentuk tongkonan, pintu gerbang rumah dan hunian, ada pada objek C. Entrance yang berbeda mewakili atap rumah sekaligus pintu gerbang. Hal itu 
terjadi karena pada kasus ini replikasi atap tongkonan tidak berada pada induk rumah, melainkan pada bagian samping rumah.

Berdasarkan analisis dengan teori golden section, fasad dari bentuk tongkonan mendekati proporsional. Keseimbangan antara lebar dan tinggi mendekati nilai keseimbangan. Nilai proporsional berdasarkan teori golden section dalam Ching adalah 1, 618. Penalaran dalam melakukan pengukuran tanpa melalui proses proyeksi titik bantu, seperti yang terjadi pada objek A. Pada struktur atap merepresentasikan keberadaan arsitektur lama di Toraja. Jika diamati pada konsep empiris, Akan terbangun dalam pola pikir pengamat tentang konstuksi tradisional yang sudah kuno. Pada penelitian mengenai klasifikasi bentuk struktur banua, maka objek B termasuk dalam bentuk atap 'tipe banua rendah dengan satu lantai'. Penutup atap bagian bawah tidak dilengkapi dengan lesplank sebagaimana dua objek lainnya dalam penelitian ini. Penampilan konstruksi atap selaras dengan konstruksi bagian bawahnya.Meskipun konstruksi bagian bawahnya terbuat dari material beton, lazimnya, setelah struktur atap maka di duduk (tongkon) pada struktur tengah dan selanjutnya struktur tengah didudukkan pada kaki struktur.

Tabel 4: Interpretasi proporsi bentuk bangunan tipe A, B dan C

\begin{tabular}{|c|c|c|}
\hline Tipe Rumah & Bagian pembentuk proporsi & Interpretasi \\
\hline \multirow[t]{3}{*}{$\begin{array}{l}\text { Rumah tipe A: } \\
\text { (tipe berpunggung } \\
\text { melengkung } \\
\text { dalam) }\end{array}$} & $\begin{array}{l}\text { Bentukatap rumah } \\
\text { Fasad depan, tampak } \\
\text { samping, longa di bagian } \\
\text { depan dan belakang }\end{array}$ & $\begin{array}{ll}\text { - } & \text { Representasi identitas Tongkonan Toraja } \\
\text { - } & \text { Lebar penampang dan tinggi atap dengan perbandingan } \\
& \text { tertentu } \\
\text { - } & \text { Berada pada tipe tongkonan berpunggung dengan atap } \\
& \text { melengkung ke dalam } \\
\text { - } & \text { Simetris melalui garis sumbu vertikal } \\
\text { - } & \text { Metafora pada bentuk dari alam (tanduk kerbau) } \\
\text { - } & \text { Bersifat tipe harmonic (pendekatan teori renaisance) }\end{array}$ \\
\hline & $\begin{array}{l}\text { Keseimbangan dengan } \\
\text { bentuk yang lama }\end{array}$ & $\begin{array}{l}\text { - Membentuk simbol yang berelasi dengan alam } \\
\text { - Ada keselarasan dengan mengadobsi keagungan dari tempat } \\
\text { puang matua }\end{array}$ \\
\hline & $\begin{array}{l}\text { Bentuk keseluruhan (bagian } \\
\text { atas, tengah dan bawah) }\end{array}$ & $\begin{array}{ll}\text { - } & \text { Transformasi dari proses sosial budaya } \\
\text { - } & \text { Mendekati nilai proporsional golden section } \\
\end{array}$ \\
\hline \multirow{3}{*}{$\begin{array}{l}\text { Rumah tipe } \\
\text { (berpunggung } \\
\text { datar) }\end{array}$} & $\begin{array}{l}\text { Bentuk atap rumah } \\
\text { - } \text { Fasad depan } \\
\text { - Longa depan }\end{array}$ & $\begin{array}{ll}\text { - } & \text { Mewakili bentuk tongkonan } \\
\text { - } & \text { Asimetris dengan garis bantu sumbu vertikal } \\
\text { - } & \text { Keunikan dan entitas bentuk atap } \\
\end{array}$ \\
\hline & $\begin{array}{l}\text { Komparasi pada bentuk yang } \\
\text { lama }\end{array}$ & - Masih memiliki bentuk mimesis dengan tongkonan \\
\hline & $\begin{array}{l}\text { Kesatuan bentuk rumah } \\
\text { (unity) }\end{array}$ & $\begin{array}{ll}\text { - } & \text { Kombinasi budaya lama dengan modern } \\
\text { - } & \text { Keseimbangan dengan lingkungan (adanya vegetasi dan } \\
& \text { bentuk tambahan) } \\
\text { - } & \text { Representasi citra kota dan budaya } \\
\text { - } & \text { Keindahan dan harmonisasi } \\
\text { - } & \text { Mendekati nilai keseimbangan golden section } \\
\end{array}$ \\
\hline \multirow[t]{2}{*}{$\begin{array}{l}\text { Rumah tipe } \\
\text { C(berpunggung } \\
\text { melengkung } \\
\text { dalam) }\end{array}$} & $\begin{array}{l}\text { Bentuk atap rumah } \\
\text { - } \text { Fasad depan } \\
\text { - Longa depan }\end{array}$ & $\begin{array}{ll}\text { - } & \text { Representasi model atap tongkonan } \\
\text { - } & \text { Simetris jika ditarik garis bantu secara vertikal } \\
\text { - } & \text { Perbedaan bentuk dengan rumah di sekitarnya } \\
\text { - } & \text { Sebagai aksentuasi } \\
\text { - } & \text { Replika tongkonan berada di depan rumah } \\
\end{array}$ \\
\hline & $\begin{array}{l}\text { Perbandingan dengan } \\
\text { arsitektur asli toraja }\end{array}$ & $\begin{array}{ll}\text { - } & \text { Kemiripan bentuk atap } \\
\text { - } & \text { Adopsi sistem susunan hirarki kepala, badan dan kaki rumah }\end{array}$ \\
\hline
\end{tabular}

Sumber: Interpretasi penulis, 2016 


\section{E. Adaptasi dan Transformasi pada Arsitektur Suku Toraja di Palopo.}

Bentuk bangunan rumah tinggal suku Toraja pada masyarakat kelas menengah keatas memiliki fasad bangunan beragam. Diantara objek penelitian rumah tinggal dalam objek-objek rumah tinggal $\mathrm{A}, \mathrm{B}$ dan $\mathrm{C}$, maka objek A merupakan objek atap tongkonan yang masih menerapkan longa depan dan belakang dengan tipe meninggi dan lengkungan dalam. Bentuk atap yang ada kini tergolong dalam kategori Banua Sanda A'riri. Banua sanda A'riri merupakan perkembangan dari Banua Tamben yaitu pergantian pondasi dari susunan atau tumpukan kayu menjadi beberapa tiang (Hartanto 2012). Berdasarkan amatan di lapangan, objek A yang memiliki ketinggian atap menjulang ke atas, tetap tampak seimbang dan proporsi. Dalam teori proporsi renaisance dalam Ching (1979), tipe objek A masuk dalam kategori harmonic dengan perbandingan 2, 3, 6. Dan jika dianalisis dengan teori golden section, juga mendekati nilai proporsional 1,628.

Karya arsitektur oleh masyarakat mencitrakan keragaman bentuk atap rumah akan tetapi tetap memberikan ciri khas rumah suku Toraja. Orang keturunan suku Toraja mendirikan bangunan. Dengan berbagai model rumah, dari sekian bentuk rumah memiliki kesamaan pada selungkup bangunan dan pemanfaatan ruang pada bagian bawah rumah. Dengan melakukan penutupan ruang bagian bawah, bangunan rumah Toraja di Palopo lebih fungsional namun tidak dapat memperlihatkan aktivitas penghuni kepada masyarakat sekitarnya.Tidak ada bentuk yang sama satu sama lainnya sehingga variasi dari elemen-lemen pembentuk arsitektural semakin kaya. Proses transformasi pada seluruh objek selalu mengadobsi prinsip pembagian atas, tengah dan bawah karena rumah tinggal yang ada cenderung selalu bersusun dua lantai.

\section{KESIMPULAN}

Penalaran formal dalam proporsi suatu bentuk bergerak suatu proyeksi paruh bentuk kepada keseluruhan elemen pembentuk objek. Bentuk bangunan akan mudah dipahami karena kompleksitas bidang pembentuk ruang yang mengarah kepada harmonisasi suatu karya arsitektural kontemporer. Proporsi bentuk terjadi pada setiap variasi rumah dan mendekati ukuran perbandingan golden section. Komponen penanda dari objek visual pada atap secara fisik tidak mengubah hakekat estetika suatu produk budaya. Bentuk rumah tinggal orang Toraja berelasi dengan bentuk atap bangunan baru yang ada lingkungan Gereja PNIEL kota Palopo serta gereja yang ada perbatasan Palopo-Toraja. Relasi tersebut tidak terlepas dari pelaku aktivitas Gereja yang mayoritas berasal dari Tana Toraja.

Terjadinya penyesuaian bentuk arsitektur dari tempat yang satu ke tempat yang lainnya. Hal itu terbukti perbedaan arsitektur masyarakat Toraja yang ada di Tana Toraja dengan yang ada di kota Palopo. Perkembangan arsitektur hunian Toraja di Palopo dalam beberapa aspek telah mengalami beberapa perubahan dari bentuk aslinya yang ada di Toraja. Beberapa aspek tersebut antara lain berupa bentuk, material, tata massa bangunan. Ada proses adaptasi yang tercakup dalam filosofi 'kontekstual'. Bentuk atap yang ikonis dengan tanduk kerbau dan perahu tradisional dapat memunculkan bentuk yang metafora. Adopsi bentuk berdasarkan analogi bentuk dari alam. Keragaman bentuk rumah masyarakat Toraja di Palopo menunjukkan lokal genius dengan menggunakan pengetahuan lokal selaras dengan teori umum dalam arsitektur.

Karya rumah masyarakat Toraja memiliki kekayaan ruang, bentuk, fungsi dan makna. Baik di tana toraja maupun di luar tana Toraja memunculkan entitas arsitektur. Di Palopo banyak bangunan yang menunjukkan identitas pemiliknya sebagai suku Toraja. Sebagai suku sub etnis kedatuan Luwu, Toraja masih ada hubungan kekerabatan dengan suku-suku lainnya yang ada di wilayah Luwu. Sebagai temuan awal dari penelitian ini maka sangat untuk dilakukan kajian lebih mendalam terhadap kasus perkasus rumah tinggal dalam satu kawasan pemukiman yang menjadi 
area masyarakat Toraja bermukim. Fenomena hunian kontemporer berbasis kearifan lokal yang menjadi relevan untuk dikembangkan di era masa kini dan yang akan datang.

Terima kasih kami ucapkan secara khusus kepada Pemerintah kota Palopo. Data dari Bapedda kota Palopo, dewan adat Kedatuan Luwu beserta para pengelola museum batara guru, Madika Bua, Badan arkeologi Sulawesi Selatan, Dinas statistik dan persandian, Dinas Kebudayaan, Dinas Pariwisata, Pengurus dan jemaah masjid jami, Pengurus gereja PNIEL klasis Palopo dan terkhusus para informan penghuni rumah Toraja dan tokoh-tokoh masyarakat yang tidak dapat disebutkan satu-persatu.

\section{DAFTAR REFERENSI}

Adams, Kathleen M., Lucia Stefanini, David S. Paul, Ray F. Robledo, E. Ricky Chan, and others. 2015. "Identity, Heritage and Memorialization: The Toraja Tongkonan of Indonesia." Writing Material Culture History, 93.

Ching, Francis D. K. 1979. Architecture, Form, Space \& Order. New York: Van Nostrand Reinhold. De Jonge, Nico. 1991. "Bijdragen Tot de Taal-, Land- En Volkenkunde." KITLV, Royal Netherlands Institute of Southeast Asian and Caribbean Studies, 356-58.

Hartanto, Johanes Raymond. 2012. "The Syncretism Form of Aluk Todolo Religion with Christianity." Ambiance 1 (1). http://majour.maranatha.edu/index.php/ambiance/article/view/399.

Idrus, Nurul Ilmi. 2016. "Mana' dan Eanan: Tongkonan, Harta Tongkonan, Harta Warisan, dan Kontribusi Ritual di Masyarkaat Toraja." Jurnal Etnografi Indonesia 1 (2): 12-26.

Jayadi, Karta, and Dian Cahyadi. 2019. “Passapu Sa'dan-Toraja.” In Prosiding Seminar Nasional LP2M UNM, 422-33. Universitas Negeri Makassar.

Lebang, Yudha Almerio Pratama. 2015. "Analisis Semiotika Simbol Kekuasaan Pada Rumah Adat Toraja (Tongkonan Layuk)." E-Journal Ilmu Komunikasi 3 (4): 158-72.

Mallgrave, Harry Francis, ed. 2006. Architectural Theory. Malden, MA: Blackwell Pub.

Marwati, and Ikrama. 2018. "Identifikasi Fungsi dan Fasad Pecinan pada Bangunan di Ruas Jalan Sulawesi Makassar." Nature: National Academic Journal of Architecture 5 (2): 135. doi:10.24252/nature.v5i2a6.

Muhadjir, Noeng. 2011. Metode Penelitian. Yogyakarta: Rake Sarasin.

Mulyadi, Yadi. 2013. “Menata Hutan Menjaga Tongkonan: Alternatif Upaya Pelestarian Budaya Toraja" 7: 10.

Norberg-Schulz, Christian. 1965. Intention in Architecture. MIT Press.

Panggarra, Robi. 2014. "Konflik Kebudayaan Menurut Teori Lewis Alfred Coser Dan Relevansinya Dalam Upacara Pemakaman (Rambu Solo') di Tana Toraja." JURNAL JAFFRAY 12 (2): 26.

Rahadian, Erwin Yuniar, Fadli Wahab, Hendrik Syaputra, and Asep Setiawan. 2013. "Kajian Karakteristik Bangunan Ikonik Pada Gedung Puspa Iptek Kota Baru Parahyangan." REKA KARSA 1 (1). http://ejurnal.itenas.ac.id/index.php/rekakarsa/article/view/45.

Sani, Andi Asrul, Bambang Supriyadi, and R. Siti Rukayyah. 2015. "Bentuk dan Proporsi Pada Perwujudan Arsitektur Vernakular Bugis, Studi Kasus: Bola Soba di Kota Watampone, Sulawesi Selatan" 17 (02): 99-110.

Sir, Mohammad Mochsen, Shirly Wunas, Herman Parung, and Jhon Patandu. 2015. "Model Tektonika Arsitektur Tongkonan Toraja." In Prosiding Seminar Nasional Sains Dan Teknologi Fakultas Teknik. Vol. 1. http://www.publikasiilmiah.unwahas.ac.id/index.php/PROSIDING_SNST_FT/article/view $/ 1155$. 
Stephany, Shandra. 2011. "Transformasi Tatanan Ruang Dan Bentuk Pada Interior Tongkonan Di Tana Toraja Sulawesi Selatan." Dimensi Interior 7 (1): pp-28.

Sumalyo, Yulianto. 2004. "Kosmologi Dalam Arsitektur Toraja." DIMENSI (Journal of Architecture and Built Environment) 29 (1). http://ced.petra.ac.id/index.php/ars/article/view/15746.

Sutrisno, Moh. 2019. "Makna Ruang Kota Palopo dalam Teritori Kedatuan Luwu." In Antologi Kota Indonesia, 2nd ed., 287-305. 2. Jakarta Barat: Omah Library.

Sutrisno, Moh, Sudaryono Sastrosasmito, and Ahmad Sarwadi. 2019. "Posi Bola of Jami Mosque as Spatial Transformation Symbol.” Journal of Islamic Architecture 5 (4): 181. doi:10.18860/jia.v5i4.5226.

Sutrisno, Moh, Sudaryono, and Ahmad Sarwadi. 2018. "Sacred Spaces: An Ethnosemiotics Study on The Ancient Center of Palopo City." In Local Geniuses Generate Future Design, 3:53-64. Yogyakarta: Duta Wacana Christian University. https://smartfad.ukdw.ac.id/index.php/smart/article/view/20.

Taylor, John G. 2014. "Edwin de Jong. Making a Living between Crises and Ceremonies in Tana Toraja: The Practice of Everyday Life of a South Sulawesi Highland Community in Indonesia." Asian Affairs 45 (2): 367-69. doi:10.1080/03068374.2014.911523.

Zulkarnain AS. 2015. "Wujud Arsitektural Rumah Tradisional Duri Asli di Kabupaten Enrekang." Nature : National Academic Journal of Architecture 2 (2): 264-71. doi:10.24252/nature.v2i2a11. 